\title{
Chronic Glucose Infusion Inhibits Development of $\beta$-Receptor Binding in Fetal Lamb Lung
}

\author{
DAVID WARBURTON, SUE BUCKLEY, LANCE PARTON, AND TERRY SALUNA \\ Developmental Lung Biology Research Center, Division of Neonatology and Pediatric Pulmonology, Department \\ of Pediatrics, University of Southern California School of Medicine. Children's Hospital of Los Angeles, \\ California 90054
}

\begin{abstract}
We used chronic fetal glucose infusion to test the hypothesis that chronic fetal hyperglycemia and hyperinsulinemia inhibit the development of $\beta$-receptor binding capapcity (Bmax) in fetal lamb lung. Glucose was infused $(14 \pm 4 \mathrm{mg} / \mathrm{kg} / \mathrm{h}$, mean $\pm \mathrm{SD})$ into eight twin and four singleton fetuses from 112 days gestation until death between 118-145 days gestation. The other eight twins and eleven additional singleton fetuses served as controls. Serum glucose levels were elevated 2 -fold and serum insulin levels were elevated 3 -fold in the glucose-infused fetuses. In the control fetuses $\beta$-receptor Bmax increased 2.5 -foll between 130 days gestation and term. However, this increase was attenuated to 1.5 -fold in the glucose infused fetuses, $p<0.01$. The $50 \%$ inhibition of $B \max$ was similar in both male and female fetuses, except that the Bmax fell to $30 \%$ lower levels in males, $p<0.01$. Chronic glucose infusion also resulted in an $\mathbf{8 0 \%}$ reduction in lung lavage saturated phosphatidylcholine content, and an $85 \%$ reduction in tracheal fluid saturated phosphatidylcholine content, $p<0.001$. Lung lavage and tracheal fluid saturated phosphatidylcholine content correlated significantly with beta receptor $\mathrm{Bmax}(r=0.9, r=0.85)$. We conclude that chronic glucose infusion inhibits the development of $\beta$ receptor binding in fetal lamb lung, and that this effect is greater in males than females. Such a mechanism could be a factor in the predisposition of infants of diabetic mothers to develop respiratory distress and could contribute to a male disadvantage in respiratory morbidity. (Pediatr Res 24: 171-174, 1988)
\end{abstract}

\section{Abbreviations}

Bmax maximal binding capacity

IDM, infant of diabetic mother

RDS, respiratory distress syndrome

SPC, saturated phosphatidylcholine

DHA, dihydroalprenolol

Maternal diabetes mellitus has been associated with a cumulative 23-fold increase in the incidence of neonatal RDS (1). Stubbs and Stubbs (2) have suggested that fetal hyperinsulinemia may be the common link between maternal hyperglycemia and RDS. However, the exact etiology of RDS among IDM remains unknown.

Received February 27, 1987; accepted March 24, 1988.

Correspondence David Warburton, B.Sc., M.B., M.R.C.P., Division of Neonatology and Pediatric Pulmonology, Children's Hospital of Los Angeles, Box 54700, Los Angeles, CA 90054.

Supported in part by a NIH Special Emphasis Research Career Award and by a Grant from the American Lung Association of Los Angeles County. L.P. was a Research Fellow of the Children's Hospital of Los Angeles.
We have shown that fetal hyperinsulinemia occuring with either hyperglycemia (3) or hypoglycemia (4) is capable of inhibiting surface active material flux into the tracheal fluid of chronically catheterized fetal lambs. In human diabetic pregnancy, chronic fetal hyperglycemia with secondary hyperinsulinimia is more likely to occur. Surface active material flux into the tracheal fluid of fetal lambs has been used by several groups as a marker of in utero surfactant production (3-6). Recently we have found that chronic fetal hyperglycemia and hyperinsulinemia also reduces the SPC content of lung lavage, and impairs lung stability to air inflation and deflation in fetal lambs (7), data that are compatible with decreased availability of surfactant in the fetal airways.

Beta-receptor binding capacity has been shown to increase during the latter part of gestation in several species and this increase can be modulated by several hormones (8). We have recently shown that surface active material flux into the tracheal fluid of fetal lambs is significantly correlated with the increase in pulmonary $\beta$-receptor binding capacity (9), and that the fetal lamb lung responds to $\beta$-agonist stimulation with increased SPC in lung lavage and improved lung stability (10).

Our study was designed to test the hypothesis that chronic hyperglycemia and hyperinsulinemia induced by chronic glucose infusion inhibit the development of $\beta$-receptor binding capacity in fetal lamb lung.

\section{METHODS}

Animal preparation. Gestational age of pregnant sheep was determined from the time of mating (Nebeker Farms, Santa Monica, CA). In addition, fetal age was estimated from ossification centers in utero (11) and by extrapolation of fetal weight and crown-rump measurements at delivery (12): dating by these methods agreed with 3 days.

Ewes were operated on at 110 days gestation under epidural anesthesia with $0.5 \%$ Pontocaine as described previously $(3,5)$. Catheters were placed in a fetal carotid artery, jugular vein, and the trachea. The tracheal catheter was connected at $600-\mathrm{ml}$ latex bag that was left in the amniotic sac. A separate catheter leading from the bag and the other catheters was exteriorized through the ewe's flank. After the operation the ewes received 1.2 million $\mathrm{U}$ procaine penicillin and $1 \mathrm{~g}$ kanamycin intramuscularly for 5 days. The fetuses received $200,000 \mathrm{U}$ penicillin and $10 \mathrm{mg}$ kanamycin intravenously every day.

Glucose infusion. Chronic hyperglycemia was produced by continuous intravenous infusion of $20 \%$ dextrose in water at a rate of $14 \pm 4 \mathrm{mg} / \mathrm{kg} / \mathrm{min}$ (mean $\pm \mathrm{SD}$ ) from 112 days gestation onward, using a constant infusion pump (IVAC Corp., San Diego, CA). Glucose infusions were given to eight twin and four singleton fetuses. The eight untreated twins, four catheterized singleton fetuses, and seven additional uncatheterized fetuses served as uninfused controls. 
Sample collection and analysis. Arterial blood samples (3.0 $\mathrm{ml}$; approximately $1 \%$ of fetal blood volume) were obtained every 48 to $72 \mathrm{~h}$ including the day of death. Arterial blood gases were measured at $39^{\circ} \mathrm{C}$ using a Corning 178 blood gas analyzer (Corning Medical and Scientific, Medfield, MA). Serum was separated from the arterial blood and stored at $-40^{\circ} \mathrm{C}$ for subsequent analysis. Serum glucose concentration in $\mathrm{mg} / \mathrm{dl}$ was measured by the glucose oxidase method using a YSI-23A glucose analyzer (Yellow Springs Instruments, Yellow Springs, $\mathrm{OH}$ ). Serum insulin concentration in $\mu \mathrm{U} / \mathrm{ml}$ was measured using a double antibody radioimmunoassay. Tracheal fluid was collected daily.

The fetuses were rapidly removed from the uterus immediately after euthanasia of the ewe and fetuses with sodium pentobarbital. The tracheal cannula was clamped and the lungs and trachea were then rapidly removed from the fetal thorax and weighed. Small pieces of the right lung were immediately frozen in liquid nitrogen and the pieces were stored at $-70^{\circ} \mathrm{C}$ for subsequent analysis. The assays reported below using lung tissue preserved by this technique were stable and reproducible over a period of several months.

The left main stem bronchus was cannulated and pressurevolume curves were recorded. Lung lavage was performed, and SPC was extracted from the lavage fluid and from the tracheal fluid exactly as described by Warburton et al. (7).

Beta-adrenergic receptor binding assay. Beta-receptor binding assays were adapted from the methods described by Cabelli and Malbon (13) and Maniscalco and Shapiro (14) as modified by Hung et al. (15), and were performed exactly as described by Warburton et al. (9) for fetal lamb lung. Control tubes containing no tissue were included in all experiments; nonspecific binding ligand to filters was always less then $0.3 \%$ of the total counts filtered. Specific binding of DHA to lung membrane preparations was analyzed in the presence of $10 \mu \mathrm{M}$ propranolol using six concentrations of DHA ranging from 0.5 to $20 \mathrm{mM}$ to span the $K$ by the method of Scatchard (16). Nonspecific binding was 18 $\pm 2 \%$ of the total binding. Protein determinations for all assays was the method of Markwell et al. (17) using bovine serum albumin as standard.

The following comparisons between the control and glucoseinfused fetuses were made using analysis of variance with Newman-Keuls test: control versus glucose-treated fetuses (118-148 days and 130-148 days gestation); males versus females for both control and glucose-treated fetuses (130-148 days gestation). Results are given as mean $\pm \mathrm{SD}$. Statistical significance was accepted with a $p<0.05$.

\section{RESULTS}

Chronic glucose infusion at a rate of $14 \pm 4 \mathrm{mg} / \mathrm{kg} / \mathrm{min}$ (mean $\pm \mathrm{SD}$ ) resulted in a 2 -fold elevation in serum glucose level from $23 \pm 3 \mathrm{mg} / \mathrm{dl}$ in the control fetuses to $48 \pm 5 \mathrm{mg} / \mathrm{dl}$ in the glucose infused fetuses, $\mathrm{p}<0.001$. Serum insulin levels were also elevated 3-fold from $15 \pm 4 \mu \mathrm{U} / \mathrm{ml}$ in the control fetuses to 45 $\pm 5 \mu \mathrm{U} / \mathrm{ml}$ in the glucose infused fetuses. $p<0.001$. Fetal arterial blood gases in the glucose infused fetuses were $\mathrm{pH} 7.4 \pm 0.02 \mathrm{U}$, $\mathrm{pO}_{2} 23.5 \pm 0.8$ torr, $\mathrm{pCO}_{2} 40.5 \pm 0.9$ torr, not significantly different from controls. The rate of tracheal fluid production was $3.6 \pm 0.6 \mathrm{ml} / \mathrm{kg} / \mathrm{h}$ in the glucose-infused fetuses, not significantly different from controls.

The effects of chronic glucose infusion on lung lavage and tracheal fluid SPC content have been reported previously in detail $(3,7)$. Briefly, chronic glucose infusion resulted in an $80 \%$ reduction in lung lavage SPC content from $0.84 \pm 0.15 \mathrm{mg} / \mathrm{g}$ wet weight in controls to $0.16 \pm 0.04 \mathrm{mg} / \mathrm{g}$ wet weight in glucose infused fetuses after 130 days gestation, $p<0.001$. Chronic glucose infusion also resulted in an $85 \%$ reduction in tracheal fluid SPC content from $0.64 \pm 0.20 \mathrm{mg}$ /day in controls to 0.09 $\pm 0.05 \mathrm{mg} /$ day in glucose infused fetuses after 130 days gestation, $p<0.001$.
Specific (-) $-\left[{ }^{3} \mathrm{H}\right] \mathrm{DHA}$ binding to fetal lung membranes was saturable, linear, and stereospecific (9).

The effect of chronic glucose infusion on $\beta$-receptor $B \max$ is shown in Figure 1. Between 130 days gestation and term Bmax increased 2.5-fold in the control fetuses $(75 \pm 35$ (7) to $184 \pm 32$ (12) $\mathrm{fmol} / \mathrm{mg}$ protein, $p<0.001)$. However, in the glucosetreated fetuses the increase in Bmax between 130 days gestation and term was attenuated to 1.5 -fold $(p<0.01)[85 \pm 19$ (4) to $130 \pm 28(4) \mathrm{fmol} / \mathrm{mg}$ protein, $p<0.001]$

A comparison of pulmonary $\beta$-receptor Bmax between male and female fetuses after 130 days gestation is shown in Table 1. Glucose infusion resulted in a $50 \%$ reduction in pulmonary Bmax in both male and female fetuses after 130 days gestation. However, the Bmax fell to $30 \%$ lower levels in males after glucose infusion. The $K$ of pulmonary $\beta$-receptors in all the fetuses was $1.3 \pm 0.4 \mathrm{nM}$ and was not significantly affected by glucose infusion or fetal gender.

We have shown previously that $\beta$-receptor Bmax correlates with surface active material flux into the tracheal fluid of fetal lambs (9). A correlation between fetal pulmonary $\beta$-receptor Bmax and lung lavage SPC content in both control and glucoseinfused fetal lambs is shown in Figure 2. A similar correlation was found between Bmax and tracheal fluid SPC content $(r=$ $0.85, p<0.005$, data not shown).

\section{DISCUSSION}

Intravenous glucose infusion to chronically catheterized fetal lambs resulted in chronic hyperglycemia and hyperinsulinemia similar to that which we have reported previously (3). Fetal arterial blood gases and tracheal fluid production rate were not significantly altered by the rate of glucose infusion reported herein. The increase in $\beta$-receptor binding capacity during the last third of gestation in both the catheterized and uncatheterized control fetuses was similar to the data we have reported previously in fetal lambs (9).

Beta-receptor-mediated mechanisms have been implicated in the control of surfactant release, as well as in the reabsorption of alveolar liquid $(10,18)$. Inhibition of $\beta$-receptor binding might therefore inhibit surfactant availability in the airways and inhibit resorption of liquid from the alveoli, effects that are compatible with the known pathophysiology of RDS. In our study, inhibition of $\beta$-receptor binding between 130 days gestation and term was found to correlate with reduced lung lavage and tracheal fluid surfactant phospholipid content.

The development of $\beta$-receptor binding capacity in the fetal lung is controlled by several hormones (8). Glucocorticoids have

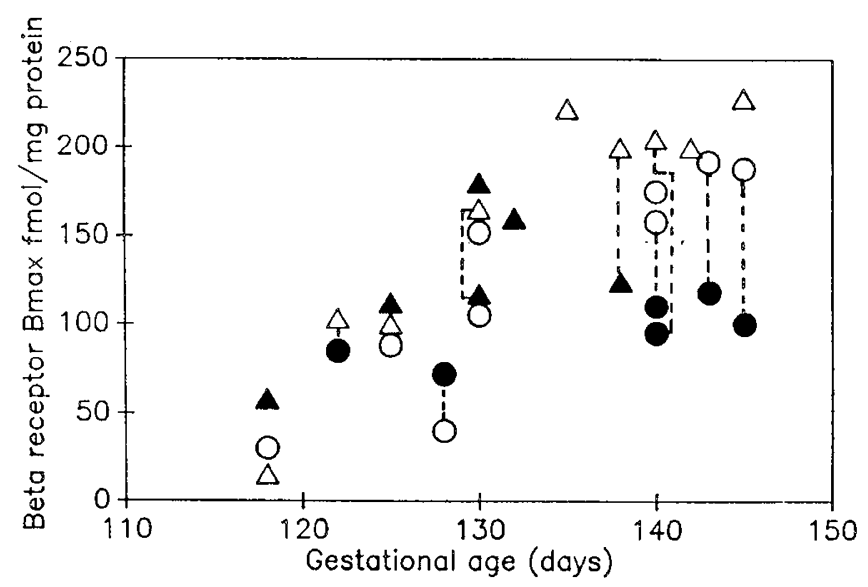

Fig. 1. Development of $\beta$-receptor Bmax in male $(O)$ and female $(\triangle)$ control and in male $(\boldsymbol{O})$ and female $(\boldsymbol{\Lambda})$ glucose-infused fetal lambs during the last third of gestation. The dotted lines joining data points indicate twin pairs. 
Table 1. Pulmonary $\beta$-receptor Bmax in 12 control and eight glucose infused fetal lambs: comparison between male and female fetuses from 130 days gestation to term*

\begin{tabular}{lcc}
\hline & Control fetuses & $\begin{array}{c}\text { Glucose-infused } \\
\text { fetuses }\end{array}$ \\
\hline Females & $200 \pm 22(6)$ & $153 \pm 26(4) \dagger$ \\
Males & $165 \pm 32(6)$ & $106 \pm 7(4) \uparrow \S$ \\
\hline
\end{tabular}

* Bmax, fmol/mg protein, mean $\pm \mathrm{SD}(n)$.

$\dagger$ Control versus glucose-infused fetuses, $p<0.02$.

$\ddagger$ Control versus glucose-infused fetuses, $p<0.01$.

$\S$ Males versus females, $p<0.01$.

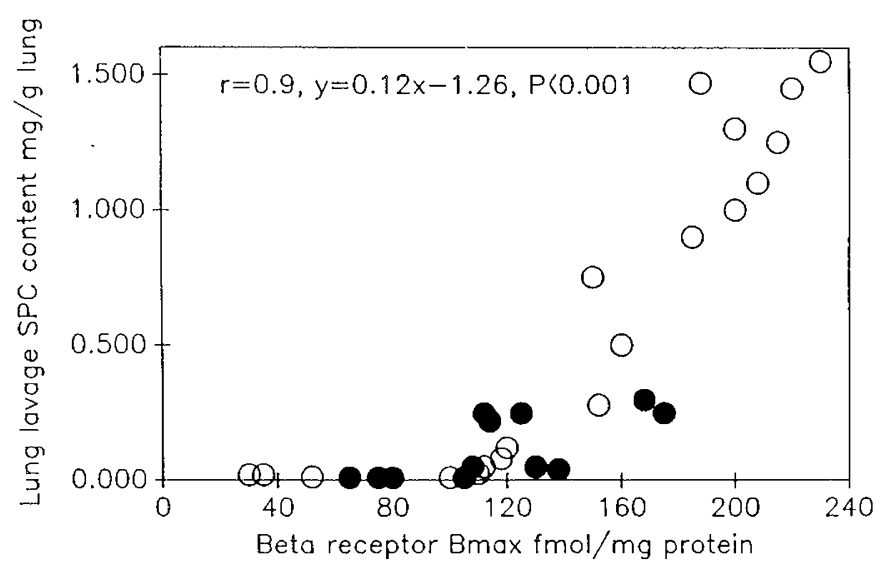

Fig. 2. Correlation of pulmonary $\beta$-receptor Bmax with SPC content of lung lavage fluid in control $(\bullet)$ and glucose-infused $(O)$ fetal lambs.

been reported to increase the $\beta$-receptor binding capacity of fetal rabbit lung (19), whereas hypothyroidism was shown to inhibit $\beta$-receptor binding capacity in fetal rat lung (20). In addition, Maniscalco et al. (14) and Warburton et al. (21) have reported synergistic effects of glucocorticoid and thyroid hormones on $\beta$ receptor binding capacity in fetal rabbit lung explants in culture and in fetal lamb lung, respectively.

We have recently reported that pulmonary $\beta$-receptor binding capacity increases more rapidly in female fetal lambs than males (9). We found that between 128-138 days gestation, pulmonary Bmax was 1.4-fold greater in females than males, but that there was no significant difference closer to term (9). In our study, the difference between male and female controls was not statistically significant because it included term fetuses. However, glucose infusion apeared to produce a significant male disadvantage in $\beta$-receptor binding capacity. Padbury et al. (22) have also reported that female rabbit fetuses develop $\beta$-receptor binding capacity earlier in gestation than do males. Male gender and dihydrotestosterone have also been reported to inhibit the development of fetal surfactant phospholipids $(23,24)$. Moreover, according to Robert et al. (1), male offspring of human diabetic mothers have a higher relative risk of developing RDS. Fatal RDS has also been noted more commonly among male IDM $(25,26)$.

It is not clear from our study if the inhibitory effects of glucose infusion on $\beta$-receptor binding are mediated by hormonal interactions at the transcriptional level or are due to local membrane effects on the surface of lung cells. We have shown that chronic glucose infusion inhibits the maturational response of the fetal lamb lung to cortisol (27). However, Neufield et al. (28) have reported increased binding capacity of insulin receptors in pulmonary membranes from the pups of alloxan diabetic rabbits and have also reported similar results in cord blood monocytes from human IDM (29), findings that were attributed to decreased membrane fluidity with increased exposure of insulin receptors at the cell surface. Brown and Longmore (30) have also recently reported quite rapid changes in the rate of surfactant secretion in response to $\beta$-agonist in type II pneumocytes freshly isolated in vitro from the lungs of Streptozotocin diabetic rats. The latter effects could be reversed by in vivo insulin treatment before death, but not by insulin treatment of the cells in vitro.

We conclude that chronic hyperglycemia and hyperinsulinemia, resulting from chronic glucose infusion, inhibits the development of $\beta$-receptor binding capacity in fetal lamb lung, and that the inhibition is greatest in glucose-infused male fetuses. We speculate that decreased binding capacity of pulmonary $\beta$-receptors may inhibit the effects of $\beta$-agonist on the fetal lung (31). Such a mechanism could be a factor in the predisposition of IDM with poor maternal glucose homeostasis to develop RDS, and could contribute to a male disadvantage in respiratory morbidity.

Acknowledgment. Mary DiNallo provided secretarial assistance.

\section{REFERENCES}

1. Robert MF, Neff RK, Hubbell JP, Taeusch HW, Avery ME 1975 Association between maternal diabetes mellitus and the respiratory distress syndrome. $\mathrm{N}$ Engl J Med 294:357-360

2. Stubbs WA, Stubbs SM 1978 Hyperinsulinemia, maternal diabetes and respiratory distress syndrome: a common link? Lancet 1:308-309

3. Warburton D 1983 Chronic hyperglycemia reduces surface active material flux in tracheal fluid in fetal lambs. J Clin Invest 71:550-555

4. Warburton D, Lew CD, Platzker ACG 1981 Primary hyperinsulinemia reduces surface active material flux in tracheal fluid of fetal lambs. Pediatr Res 15:1422-1424

5. Mescher EJ, Platzker ACG, Ballard PL, Kitterman JA, Clements JA, Tooley WH 1975 Ontogeny of tracheal fluid, pulmonary surfactant and plasma corticoids in the fetal lamb. J Appl Physiol 39:1017-1021

6. Platzker ACG, Kitterman JA, Mescher J, Clements JA, Tooley WH 1975 Surfactant in the lung and tracheal fluid of the fetal lamb and acceleration of its appearance by dexamethasone. Pediatrics 56:554-561

7. Warburton D, Parton L, Buckley S, Cosico L, Enns G, Saluna T 1987 Effects of glucose infusion on surfactant and glycogen regulation in fetal lamb lung. J Appl Physiol 63:1750-1756

8. Ballard PL 1986 Hormones and Lung Maturation. Monogr Endocrinol 28:236-277

9. Warburton D, Parton L, Buckley S, Cosico L, Saluna T 1987 Beta receptors and surface active material flux in fetal lambs: female advantage. $J$ App Physiol 63:828-833

10. Warburton D, Parton L, Buckley S, Cosico L, Saluna T 1987 Effects of preferential beta-2 agonist on tracheal fluid flow, surfactant, and pulmonary mechanics in the lamb lung. J Pharmacol Exp Ther 242:394-398

11. Lascelles AK 1959 The time of appearance of ossification centers in the peppintype merino. Aust $\mathbf{J}$ Zool 7:79-86

12. Barcroft J 1947 Researches on Pre-Natal Life, Vol 1. Charles C Thomas, Springfield, IL

13. Cabelli RJ, Malbon CC 1979 Characterization of $(-)-{ }^{3} \mathrm{H}$ dihydroalprenolol binding sites on isolated fat cells. J Biol Chem 248:8903-8908

14. Maniscalco WM, Shapiro DL 1983 Effects of dexamethasone on beta adrenergic receptors in fetal lung explants. Pediatr Res 17:274-277

15. Hung CR, Hong JS, Bondy SC 1982 The prevention of an artifact in receptor binding assay by an improved technique. Life Sci 30:1713-1720

16. Scatchard G 1951 The attraction of proteins for small molecules and ions. Ann NY Acad Sci 51:660-672

17. Markwell MA, Haas SM, Bieber LL, Tolbert NE 1978 A modification of the Lowry procedure to simplify protein determinations in membrane and lipoprotein samples. Anal Biochem 87:206-210

18. Lawson EE, Brown ER, Torday JS, Madansky DL, Taeusch HW 1978 The effects of epinephrine on tracheal fluid flow and surfactant efflux in fetal sheep. Am Rev Respir Dis 1 18:1023-1026

19. Cheng JB, Goldfien A, Ballard PL, Roberts JM 1980 Glucocorticoids increase pulmonary beta adrenergic receptors in fetal rabbit. Endocrinology 107:1646-1648

20. Whitsett JA, Darovec-Beckerman C, Pollinger J, Moore JJ Jr 1982 Ontogeny of beta adrenergic receptors in the rat lung: effects of hypothyroidism. Pediatr Res 16:381-387

21. Warburton D, Parton L, Buckley S, Cosico L 1988 Combined effects of glucocorticoids, thyroid hormones, and $\beta$-agonist on surfactant, pulmonary mechanics, and $\beta$-receptor binding in fetal lamb lung. Pediatr Res 24:166170

22. Padbury JF, Hobell CJ, Lam RW, Fisher DA 1981 Sex differences in lung and adrenal neurosympathetic development in rabbits. Am J Obstet Gynecol 141:199-204

23. Nielsen HC, Torday JS 1987 Sex differences in fetal rabbit pulmonary surfactant production. Pediatr Res 15:1245-1251

24. Nielsen HC, Zinman HM, Torday JS 1982 Dihydrotestosterone inhibits fetal 
pulmonary surfactant production. J Clin Invest 69:611-616

25. Usher RH, Allen AC, McLean FH 1971 Risk of respiratory distress syndrome related to gestational age, route of delivery, and maternal diabetes. Am J Obstet Gynecol 111:826-832

26. Farrell PM, Wood RE 1976 Epidemiology of hyaline membrane disease in the United States. Pediatrics 58:167-176

27. Warburton D 1983 Chronic hyperglycemia with secondary hyperinsulinemia inhibits the maturational response of the fetal lamb lung to cortisol. J Clin Invest 72:433-440

28. Neufeld ND, Corbo LM, Kaplan SA 1981 Plasma membrane insulin receptors in fetal rabbit lung. Pediatr Res 15:1058-1062

29. Neufeld ND, Corbo LM 1984 Membrane fluid properties of cord blood mononuclear leukocytes: Association with increased insulin receptors. Pediatr Res 18:773-778

30. Brown LAS, Longmore W 1986 Altered phospholipid secretion in type II pneumocytes isolated from streptozotocin-diabetic rats. Biochem Biophys Acta 878:258-265

31. Warburton D, Parton L, Buckley S, Cosico L, Enns G, Saluna T 1987 Chronic glucose infusion inhibits beta receptor maturation and the response of fetal lamb lung to beta agonist. Pediatr Res 21:348A 